\title{
Eco-efficiency Level of Production Process of Waste Cooking Oil to be Biodiesel with Life Cycle Assessment
}

\author{
Sri Hartini*, Diana Puspitasari, Nabila Roudhatul Aisy, Yusuf Widharto \\ Department of Industrial Engineering, Diponegoro University, Indonesia
}

\begin{abstract}
Lack of awareness and knowledge of environmental protection, many people discard cooking oil waste. According to several studies, cooking oil waste can be processed into more valuable products through certain processes that require energy and material. Biodiesel is an example. Beside biodiesel, the production process also produces non-product output. Thus, efforts to utilize cooking oil waste into more valuable products also have a negative impact on the environment. This study aims to measure the environmental impact of biodiesel production from waste cooking oil and compare it if it is discharged to landfill without the recycling process. Measurement of environmental impacts is carried out using a Life Cycle Assessment. Measurement of the environmental impact of biodiesel processing from cooking oil waste is based on a process carried out at a research institute. The measurement results state that the disposal of cooking oil waste has an adverse effect on the ecotoxicity category. Whereas the processing of cooking oil waste into biodiesel has advantages in the categories of climate change, the formation of photochemical oxidants, fine dust, oil and gas depletion, and water pressure indicators. the level of eco efficiency from processing waste cooking oil to biodiesel produces a value close to one which means that the production process is affordable but not yet sustainable.
\end{abstract}

\section{Introduction}

The issue of improper management of waste cooking oil (WCO) is attracting public concern and serious attention in recent years[1]. Indonesia is the largest palm oil producer in the world with palm oil as one of its derivative industries[2].I n 2018, Indonesia's crude palm oil production reaches 29 million tons, of which $28 \%$ is used for edible oil (8.41 million tons). The allocation of palm oil as cooking oil causes a high amount of waste and is harmful to the environment[3]. Fast food restaurants in big cities in China can produce cooking oil waste of about 15 litres every day[4]. In the Mediterranean country, one person produces $3-5 \mathrm{~kg}$ WCO each year[5]. A survey in the Greater Jakarta area concluded that $1,889,506$ tons of waste cooking oil was dumped in the gutters and soil every week. A survey at 347 households in Semarang estimated that around $90.4 \%$ of households preferred

* Corresponding author: srihartini@lecturer.undip.ac.id 
to dispose of WCO instead of recycling. The most common behavior is to dispose of the waste cooking oil with the details $66 \%$ to the drains, $8.6 \%$ to the land, and $15.8 \%$ to the trash. It is estimated, there are around 252,271 litres of WCO disposed of. This is because not everyone understands the impact caused by WCO's mistreatment. Only $54.9 \%$ of the participants understand the dangers of disposing WCO to landfills[6]. WCO can disrupt aquatic ecosystems because water surface closure and inhibit oxygen diffuse[7]. It could cause environmental problems due to improper waste management and dispose of WCO from households and restaurants directly to drainage. Such actions will lead to serious environmental problems like that as water and soil pollution which consequently affects health humans, plants and most of aquatic life, plus produce higher costs for wastewater treatment to eliminate WCO.

Whereas the recycling process can reduce waste, reduce dependence on fossil fuel energy, and reduce pollutant emissions[8]. Waste cooking oil can actually be collected and then used as biofuel, soap, detergent, paint, or lubricant[9]. The processing of cooking oil waste as one way to realize a sustainable production process is expected to reduce adverse impacts on the environment. Biodiesel is known as a beneficial alternative energy source as a substitute for conventional petroleum fuels which is currently the most commonly used as fuel[10]. Biodiesel has several advantages over conventional fossil fuels such as low toxicity, high oxygen content (10-11\%), better combustion efficiency, and, most importantly, biodegradable[11]. The adoption of biodiesel that is economically feasible and environmentally friendly will change the direction of the world to be cleaner. The weakness of biodiesel lies in the higher production costs compared to conventional fossil fuels because of the high cost of raw materials and homogeneous catalyst systems[12]. To overcome the high cost of raw materials, WCO can be an alternative raw material. WCO has lower prices and high availability compared to palm oil, soybean, and sunflower oil as pure vegetable oils. Of course, WCO requires additional refining costs[13].

The study aims to assess the environmental impact of processing WCO into biodiesel compared to the environmental impact when discharged into landfills. The measurement is based on the production process carried out at a research institute. The measurement of environmental impacts was done using SimaPro software.

\section{Methods}

\subsection{Life cycle Assessment}

Sustainable Development is an urgent problem that requires action and change from the government, industry, and society as a whole[14]. According to Melnyk[15], sustainable manufacturing is a system that integrates product design and process design with manufacturing, planning, and control to identify, measure, assess, and manage waste to minimize adverse impacts on the environment and maximize resource efficiency. Sustainable manufacturing has several aspects namely social, economic, and environment which is interrelated in regulating environmental protection and natural resource laws[16].

Life cycle assessment (LCA) is an internationally recognized standard for estimating the environmental impact of a product, process, or activit [17]. LCA helps decision-makers to identify and measure the environmental impact of a product, process, or activity during its entire life cycle. LCA is carried out in several stages, including defining goals and scope, inventory analysis, impact assessment, and interpretation[18, 10, 19, 20]. 


\subsubsection{Goal and Scope}

This study aims to compare the environmental impact between WCO that is discharged without recycling and WCO which is processed into biodiesel. The adverse effects of used cooking oil disposal on the environment are based on compounds contained in WCO from Taufiqurrahmi [21] (Table 1). While the measurement of WCO into biodiesel is based on observations on the production process of biodiesel made from WCO at a research institute. The biodiesel production process from WCO is shown in Fig 1.

Table 1. Compounds in Waste Cooking Oil [21]

\begin{tabular}{lrr}
\hline \multicolumn{1}{c}{ Fatty Acids } & Prercentage & \multicolumn{1}{c}{ CAS Number } \\
\hline Lauric Acid & $1.10 \%$ & $143-07-7$ \\
Miracic Acid & $3.21 \%$ & $544-63-8$ \\
Palmitic Acid & $21.47 \%$ & $200-312-9$ \\
Palmitoleic Acid & $7.56 \%$ & $373-49-9$ \\
Heptadecanoic Acid & $0.51 \%$ & $506-12-7$ \\
Oleic Acid & $28.64 \%$ & $112-80-1$ \\
Linoleic Acid & $13.58 \%$ & $60-33-3$ \\
Linolenic Acid & $1.59 \%$ & $463-40-1$ \\
Arachidic Acid & $0.64 \%$ & $506-30-9$ \\
Eicosadienoic Acid & $0.29 \%$ & $2091-39-6$ \\
Arachidonic Acid & $0.37 \%$ & $506-32-1$ \\
Others & $8.04 \%$ & - \\
\hline
\end{tabular}

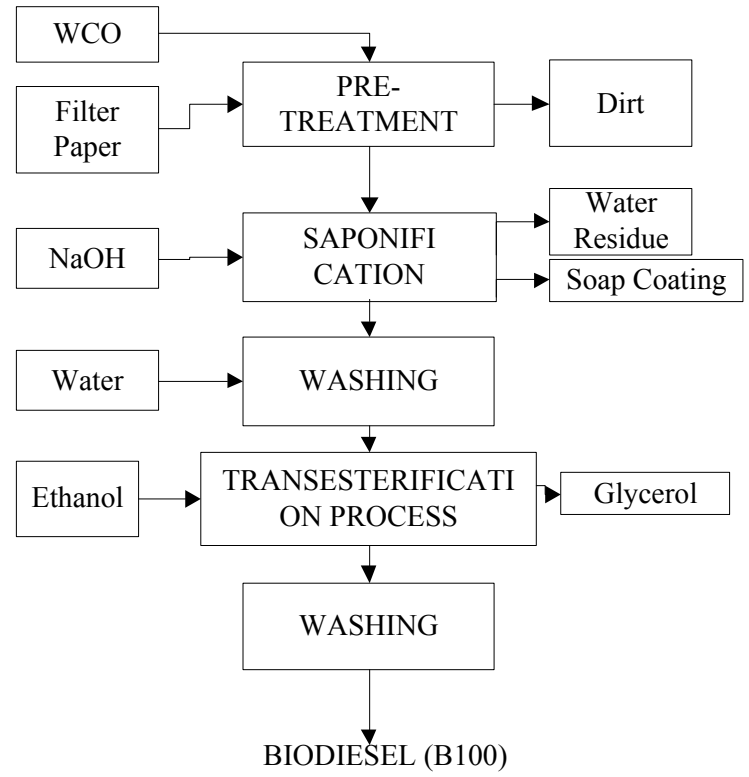

Fig. 1. Scope: Proses Pembuatan Biodisel dari Minyak Goreng Bekas 


\subsubsection{Life Cycle Inventory (LCI)}

Life cycle inventory analysis - focusing on input and output data acquisition for material and energy flow from the WCO production process system into biodiesel.

\subsubsection{Life Cycle Impact Assessment (LCIA)}

The three mandatory components of the third stage - life cycle impact assessment - include (i) selection of impact categories, indicators, and characterization models, (ii) classification to link impact categories and inventory data, and (iii) characterization to calculate the values for the category indicators[22].

\subsubsection{Interpretation}

The fourth stage is the interpretation of the results, which summarizes and discusses the results of the analysis to provide conclusions and recommendations in accordance with the goals and scope of the study.

\subsection{Eco-Efficiency}

The results of the measurement of environmental impact will be used as the basis for measuring Eco-efficiency as one of the parameters of the clean production strategy. Ecoefficiency is an index of environmental cost-effectiveness calculated by comparing the net value with production costs and Eco-costs [23 - 25]. The value of eco efficiency can be taken into consideration in assessing the sustainability of a system. An eco-efficiency value of less than 1 means the system is not affordable. if the value ranges from $0-1$ means affordable. If the value is more than one, it means that the system is both affordable and sustainable [26]. The higher the ratio, the better the eco-efficiency and vice versa. Higher environmental efficiency also means that environmental impacts and costs are very low [27]. Assessing Eco-efficiency can be a bridge for practical industries in supporting sustainable development[27].

\section{Result}

\subsection{Impact of Waste Cooking Oil Disposal}

WCO which is disposal without going through the process of recycling contains compounds that have an ecotoxicity (freshwater) effect of 0.43 PAF.m3.day which is equivalent to an environmental cost of 2.39E-6 euros.

\subsection{Environmental impact of Biodiesel Processing}

\subsubsection{Life-Cycle Inventory}

Material and energy data input in making biodiesel from WCO is measured based on the production process carried out at the Research and Technology Center. The results are explained in Table 2 . 
Table 2. Life Cycle Inventory

\begin{tabular}{lcc}
\hline \multicolumn{1}{c}{ Input } & Total & Unit \\
\hline Pretreatment phase & & \\
Filter paper & 0.10 & $\mathrm{~kg}$ \\
Electricity & 0.05 & $\mathrm{kWh}$ \\
Water & 0.50 & $\mathrm{~kg}$ \\
$\mathrm{NaOH}$ & 0.05 & $\mathrm{~kg}$ \\
Transesterification phase & & \\
Ethanol 96\% & 0.20 & $\mathrm{~kg}$ \\
$\mathrm{NaOH} 2 \mathrm{~N}$ & 0.05 & $\mathrm{~kg}$ \\
Water & 0.50 & $\mathrm{~kg}$ \\
Electricity & 0.05 & $\mathrm{kWh}$ \\
Final Product & & \\
Soap Coating & 0.25 & $\mathrm{~kg}$ \\
Biodiesel & 0.75 & $\mathrm{~kg}$ \\
Glycerin & 0.50 & $\mathrm{~kg}$ \\
\hline
\end{tabular}

\subsubsection{Life Cycle Impact Assessment (LCIA)}

Characterization of biodiesel processing from waste cooking oil and eco cost are shown in Table 3 . The total environmental cost of processing biodiesel from waste cooking oil with the eco cost method is IDR 907 (1 euro = IDR 16,025, March 13, 2019).

Table 3. Characterization of Biodiesel from $\mathrm{WCO}$ and eco cost

\begin{tabular}{llrrr}
\hline \multicolumn{1}{c}{ Impact Category } & \multicolumn{1}{c}{ Unit } & \multicolumn{1}{c}{ Total } & \multicolumn{1}{c}{ Euro } & \multicolumn{1}{c}{ IDR } \\
\hline Climate Change & $\mathrm{kg} \mathrm{CO}_{2}$ eq & $-1.40 \mathrm{E}+00$ & $-0.16 \mathrm{E}+00$ & $-2,596.05$ \\
Acidification & $\mathrm{kg} \mathrm{SO}_{2} \mathrm{eq}$ & $6.37 \mathrm{E}-02$ & $0.56 \mathrm{E}+00$ & $8,925.93$ \\
Eutro-phication & $\mathrm{kg} \mathrm{PO}_{4}-\mathrm{eq}$ & $3.99 \mathrm{E}-03$ & $1.67 \mathrm{E}-02$ & 267.62 \\
Photo-ch. Oxidant Form. & $\mathrm{kg} \mathrm{C}_{2} \mathrm{H}_{4} \mathrm{eq}$ & $-2.85 \mathrm{E}-03$ & $-2.96 \mathrm{E}-02$ & -474.34 \\
Fine Dust & $\mathrm{kg} \mathrm{PM} 2.5 \mathrm{eq}$ & $-9.42 \mathrm{E}-04$ & $-3.2 \mathrm{E}-02$ & -512.80 \\
Human Toxicity & $\mathrm{Cases}$ & $1.52 \mathrm{E}-08$ & $1.39 \mathrm{E}-02$ & 222.75 \\
Ecotoxicity (freshwater) & PAF.m ${ }^{3}$.day & $2.39 \mathrm{E}+03$ & $1.33 \mathrm{E}-02$ & 213.13 \\
Metal Scarcity & Euro & $3.78 \mathrm{E}-02$ & $3.78 \mathrm{E}-02$ & 605.75 \\
Oil \& Gas Dep. excl. energy & $\mathrm{kg} \mathrm{oil} \mathrm{equ}$ & $-3.33 \mathrm{E}-03$ & $-2.66 \mathrm{E}-03$ & -42.63 \\
Waste & $\mathrm{MJ}$ & $0.17 \mathrm{E}+00$ & $1.85 \mathrm{E}-03$ & 29.65 \\
Land-use & $\mathrm{Xio} \mathrm{Factor}$ & $\mathrm{X}$ & $\mathrm{X}$ & $\mathrm{X}$ \\
Water Stress Indicator & WSI factor & $-0.36 \mathrm{E}+00$ & $-0.36 \mathrm{E}+00$ & $-5,720.93$ \\
\hline
\end{tabular}

\subsection{Eco Efficiency Index}

Production costs involving the costs of raw materials, energy, labor, depreciation and overhead (Table 4). Overhead costs involve monthly electricity costs. The cost is calculated with a capacity of $1,606,081$ litres/month carried out by 10 workers. This amount is based on a survey conducted by Vanessa \& Bouta [28] regarding the potential for waste in Jakarta of $1,889,506 \mathrm{~kg} /$ week. If it is assumed that the amount that can be collected is only $25 \%$ with a specific gravity of 0.85 . 
Table 4 Production Cost

\begin{tabular}{lcrr}
\hline \multicolumn{1}{c}{ Cost Element } & Unit & Unit Cost (IDR) & \multicolumn{1}{c}{ Total (IDR) } \\
\hline WCO & Litre & 3,500 & $5,621,283,500$ \\
Others material and & Litre & 1,500 & $2,409,121,500$ \\
Energy & Man-month & $3,840,000$ & $38,400,000$ \\
Workers & Month & 333,334 & 333,334 \\
Depreciation & Month & $41,937,000$ & $41,937,000$ \\
Overhead & Total (per 1,606,081 litres per month) & & $8,111,025,333$ \\
\hline
\end{tabular}

The depreciation cost of the equipment is obtained from the depreciation of a boiler engine with a capacity of 200 litres, and 40 separators of 5 litres. The depreciation method used is the cost of straight-line depreciation without any residual value with a warranty life of 5 years and 10 years, respectively. Electricity costs are determined based on office and factory electricity costs of $150 \mathrm{~m} 2$ with an assumption of $140 \mathrm{kWh} / \mathrm{m} 2$. Based on calculations, the total cost required with a capacity of 1,606,081 litres/month is IDR $8,111,025,333$ or IDR 5050/litre. If the price of biodiesel can be sold in the range of IDR 10,675 , then a profit of around IDR 5,625 is obtained. Therefore, the Eco-Efficiency Index obtained is 0.94 .

Based on the sustainability criteria set by Voghlander, biodiesel production is an affordable but not sustainable process. This shows that biodiesel production still provides a profit but the environmental costs are still not comparable with the profit generated. However, with a value approaching number 1, then with improvements made, the biodiesel production process from WCO can reach more than 1 so that it can be said to be an affordable and sustainable process.

\section{Discussion}

The results of calculations with SimaPro stated that the WCO removed will have an ecotoxicity (freshwater) effect of 0.43 PAF.m3.day. for every litre. PAF.m3.day is the number of poison units in the waters against the amount of weight removed[29]. The disposal of used cooking oil has an impact on the ecosystem category of 2.39E-06, or equivalent to IDR 0.038 for each litre. If the supply capacity is $1,606,081$ litres per month, the environmental impact costs must be around IDR 61,031.

Biodiesel processing from WCO has negative environmental impacts in the category of climate change, photochemical oxidant formation, fine dust, oil \& gas depletion exclude energy, and water stress indicator. Negative values on SimaPro results are common. This indicates the benefits obtained by the presence of substances in the production process with a negative characterization factor. The compounds contained are recognized to contribute to global cooling. For example, $\mathrm{CO} 2$ which represents long-term carbon sequestration. Besides having an impact with a negative value, several categories in the process of biodiesel production have a positive value, including acidification, eutrophication, human toxicity, ecotoxicity (freshwater), metal scarcity, and waste. The category of acidification and eutrophication is caused by accumulation exceedance (AE)[30]. While the value of eutrophication is caused by the presence of phosphate waste which is discharged from the production process. The category of human toxicity illustrates that there are at least $1.52 \times$ 10-8 cases that might occur due to processing this biodiesel. This category can be caused by adverse effects from other categories such as acidification and others. Likewise with the ecotoxicity category, this biodiesel processing allows contamination of $2.39 \times 103$ species 
in one volume per day due to biodiesel processing. The use of equipment with metal causes an impact on the metal scarcity category. While the disposal in the production process in the form of a layer of soap produced from the pre-treatment purification process and glycerol from the transesterification process causes a waste impact. These impacts cause a high eco cost value so the eco-efficiency index is less than 1 . Biodiesel processing is included in the second category, which is affordable but not sustainable. This condition illustrates that biodiesel processing is financially affordable but not environmentally friendly.

The results of this study stated that the total impact of processing WCO into biodiesel was greater than if WCO was disposed. This is caused by a biodiesel production process from WCO that also requires energy and material. However, biodiesel processing also has positive value in several categories which means that the treatment process provides environmental benefits. Even though the eco-cost of processing WCO into biodiesel is higher than being disposed of, it is still affordable to do. Some improvements such as utilizing waste into value-added products or process efficiency so that reducing production costs are expected to increase eco efficiency value more than 1 .

Compared to fossil oil, biodiesel production from WCO has a less environmental impact (Table 5). The environmental impact of conventional diesel production is higher than biodiesel production from WCO[30]. Biodiesel processing from WCO has a lower impact on the categories of abiotic depletion, global warming, and photochemical oxidation. Whereas in the acidification and eutrophication category, the processing of biodiesel from WCO has a higher impact than processing fossil diesel and biodiesel from palm oil. This high value of acidification and eutrophication is caused by the use of boiler machines and wastewater from the saponification process. Wastewater is very likely to contain soap. Both of these factors can be reduced by replacing industrial boilers with boiled devices that are more environmentally friendly, or by treating soap waste as a non-output product into a more valuable product.

Table 5. Comparison of Environmental Impacts: Waste Cooking Oil Biodiesel, Fossil Diesel and Palm Biodiesel.

\begin{tabular}{lcccc}
\hline \multicolumn{1}{c}{ Impact Category } & Unit & $\begin{array}{c}\text { WCO- } \\
\text { Biodiesel }\end{array}$ & $\begin{array}{c}\text { Diesel } \\
\text { Fossil } \\
{[31]}\end{array}$ & $\begin{array}{c}\text { Falm Oil - } \\
\text { Biodiesel } \\
{[32]}\end{array}$ \\
\hline Abiotic depletion & $\mathrm{kg} \mathrm{Sb} \mathrm{eq}$ & $8.71 \mathrm{E}-06$ & $2.37 \mathrm{E}-02$ & $3.79 \mathrm{E}-05$ \\
Acid-ification & $\mathrm{kg} \mathrm{SO}_{2}$ eq & $6.33 \mathrm{E}-02$ & $5.40 \mathrm{E}-03$ & $1.06 \mathrm{E}=03$ \\
Eutro-phication & $\mathrm{kg} \mathrm{PO}_{4}$ eq & $1.48 \mathrm{E}-02$ & $2.76 \mathrm{E}-04$ & $1.04 \mathrm{E}-03$ \\
Global Warming & $\mathrm{kg} \mathrm{CO}_{2}$ eq & $-1.28 \mathrm{E}+00$ & $0.49 \mathrm{E}+00$ & $0.19 \mathrm{E}+00$ \\
Photo-chemical Oxidation & $\mathrm{kg} \mathrm{C}_{2} \mathrm{H}_{4}$ & $-1.09 \mathrm{E}-03$ & $3.39 \mathrm{E}-04$ & $3.45 \mathrm{E}-04$ \\
\hline
\end{tabular}

Biodiesel processing from WCO produces soap and glycerin waste. At present, the waste has not been utilized. Disposing of soap and glycerin without recycling has a negative impact on the environment. Disposing of soap in the environment can cause eutrophication or increased levels of phosphate in the aquatic environment. Measurement with Simapro software produces information that the disposal of glycerin in landfills can cause freshwater ecotoxicity of 0.03 . In fact, glycerin can be used as a raw material for the synthesis of glycerin acetate and other glycerin derivatives. According to Prasetyo (2012), glycerin derivatives can be used as food, pharmaceutical, cosmetic, and industries. If glycerin is not treated, it will only become waste that pollutes the environment. Another non-output product is the soap layer produced from the saponification process at the pretreatment stage. This layer of soap can be processed into a proper soap rather than just being thrown into landfills and causing toxic effects in water, as well as disrupting aquatic life such as fish, shellfish, snails, and plankton. 
Based on economic aspects, processing biodiesel from WCO is more profitable than processing biodiesel from palm oil. This is caused by the price of Crude Palm Oil (CPO) is much higher than the price of WCO. The high price of palm oil causes the eco-efficiency value of biodiesel with palm oil to be lower compared to used cooking oil. In addition, the production of pure palm oil also requires land for palm oil planters.

Based on social aspects, the production of biodiesel from cooking oil can create jobs. In addition, purchasing waste from the community will increase income for the community and reduce the disposal of used cooking oil in waterways. The use of glycerol and soap layers into more valuable products can also absorb labor and increase profits for the company. Based on this, the recommendation that can be given is by processing waste glycerol and soap into other industrial materials that have economic value and are better for the environment.

Based on economic aspects, processing biodiesel from WCO is more profitable than processing biodiesel from palm oil. This is caused by the price of Crude Palm Oil (CPO) is much higher than the price of WCO. The high price of palm oil causes the eco-efficiency value of biodiesel with palm oil to be lower compared to used cooking oil. In addition, the production of pure palm oil also requires land for palm oil planters.

Based on social aspects, the production of biodiesel from cooking oil can create jobs. In addition, purchasing waste from the community will increase income for the community and reduce the disposal of used cooking oil in waterways. The use of glycerol and soap layers into more valuable products can also absorb labor and increase profits for the company. Based on this, the recommendation that can be given is by processing waste glycerol and soap into other industrial materials that have economic value and are better for the environment.

\section{Conclusion}

WCO Disposal has an adverse effect on the ecotoxicity category. However, processing biodiesel from used cooking oil has an impact on all categories because recycling requires material and energy during the transformation process. However, the processing of used cooking oil into biodiesel also has environmental benefits in the category of climate change, photochemical oxidant formation, fine dust, oil and gas depletion, and water stress indicator. The eco-efficiency index for processing biodiesel from used cooking oil is close to 1 so that it can be said to be affordable, but not yet sustainable. The recommended improvement is by raising the price of biodiesel or by treating soap and glycerol waste to reduce the environmental impact.

Biodiesel from used cooking oil has a better environmental impact than biodiesel from pure palm oil or fossil diesel in several categories, including abiotic depletion, global warming, and photochemical oxidation. Biodiesel from used cooking oil is cheaper than pure palm oil. Socially, the processing of used cooking oil into biodiesel can absorb labor. Further research can be done by examining using other materials as a catalyst or conducting a feasibility test if WCO is processed into biodiesel in an area.

\section{References}

[1] R. Yang, W. Tang, R. Dai, and J. Zhang, J. Clean. Prod., 201 (2018).

[2] E. Kusrini and R. Primadasa, Failure analysis of shaft circulating water pump (CWP) used in power plant in MATEC Web Conf., 159 (2018).

[3] D. Panadare and V. K. Rathod, Biocatal. Agric. Biotechnol., 14 (2018).

[4] N. H. Abdullah, S. H. Hasan, and N. R. M. Yusoff, Int. J. Mater. Sci. Eng., 1, 2 
(2014).

[5] A. Mannu, G. Vlahopoulou, V. Sireus, G. L. Petretto, G. Mulas, and S. Garroni, Nat. Prod. Commun., 13, 5 (2018).

[6] S. Hartini, D. P. Sari, and A. A. Utami, The use of consumer behavior to identify the flow mapping of waste cooking oil: A finding from Semarang, Indonesia, in IOP Conference Series: Materials Science and Engineering, 2019, Bali-Indonesia.

[7] L. C. Lange and A. F. M. Ferreira, Waste Manag., 61 (2017).

[8] T. R. P. Ramos, M. I. Gomes, and A. P. Barbosa-Póvoa, Waste Manag., 33, 8 (2013).

[9] A. Talebian-Kiakalaieh, N. A. S. Amin, and H. Mazaheri, Appl. Energy, 104 (2013).

[10] Z. L. Chung et al., Biocatal. Agric. Biotechnol., 21 (2019).

[11] Y. H. Tan, M. O. Abdullah, J. Kansedo, N. M. Mubarak, Y. S. Chan, and C. Nolasco-Hipolito, Renew. Energy, 139 (2019.

[12] T. S. Singh and T. N. Verma, Biocatal. Agric. Biotechnol., 20 (2019).

[13] A. R. Gupta and V. K. Rathod, Waste Manag., 79 (2018).

[14] B. Silvestre and D. M. Țîrcă, J. Clean. Prod., 208 (2019).

[15] S. Melnyk, J. Oper. Manag., 21, 3 (2003).

[16] M. A. Rosen and H. A. Kishawy, Sustainability, 4, 2 (2012).

[17] C. Bessou et al., Int. J. Life Cycle Assess., 21, 3 (2016).

[18] The International Standards Organisation, The Int. of LCA, (2006).

[19] H. Prastawa and S. Hartini, The influence of product design on environmental impacts using life cycle assessment in AIP Conference Proceedings, Bali, Indonesia (2019).

[20] K. Obaideen et al., Analysis of the human health damage and ecosystem quality impact of the palm oil plantation using the life cycle assessment approach in IOP Conf. Ser. Earth Environ. Sci., (2019).

[21] N. Taufiqurrahmi, A. R. Mohamed, and S. Bhatia, Bioresour. Technol., 102, 22 (2011).

[22] A. Valente, D. Iribarren, and J. Dufour, J. Clean. Prod., 207 (2019).

[23] J. Vogtlander, VSSD, (2014).

[24] D. I. Rinawati, Sriyanto, D. Puspita Sari, and A. Cantya Prayodha, "Eco-efficiency Analysis of Furniture Product Using Life Cycle Assessment," E3S Web Conf., 31 (2018).

[25] R. Purwaningsih, C. F. Simanjuntak, and Z. F. Rosyada, Jurnal Teknik Industri, 22, $1(2020)$

[26] J. G. Vogtlander, A. E. Scheepens, N. M. P. Bocken, and D. Peck, J. Remanufacturing, 7, 1 (2017).

[27] C. M. Mah, T. Fujiwara, and C. S. Ho, J. Clean. Prod., 172 (2018).

[28] Vanessa, M. C. \& Bouta, J. M., Surya University, 2017.

[29] Ecetoc, Tech. Rep. 127 (2016).

[30] S. Vieira, W. H. L. Pinaya, and A. Mechelli, Neurosci. Biobehav. Rev., 74, (2017).

[31] M. Ripa, C. Buonaurio, S. Mellino, G. Fiorentino, and S. Ulgiati, Int. J. Performability Eng., 10, 4 (2014).

[32] D. F. Soraya, S. H. Gheewala, S. Bonnet, and C. Tongurai, J. Sustain. Energy Environ., 5 (2013). 